\title{
Devrialemde Türkiye Cumhuriyeti Durağı: Emden Kruvazörünün İstanbul'a Gelişi
}

\author{
Evrim ŞENCAN GÜRTUNCA*
}

ÖZ

Bu çalışma, Almanya'nın I. Dünya Savaşından sonra inşa ettiği ilk hafif kruvazör olan ve yaptığı dünya turu kapsamında, 1929 yllinda İstanbul'a demirleyen Emden gemisi ile ilgilidir.

1929 yll hem İstanbul hem dünya açısından önem arz eden bir yıldır. 1929’un kış mevsimi, İstanbul'un en sert kışlardan biri olarak tarihe geçmiştir. Aynı yıl dünya, çok büyük bir ekonomik krizi, Büyük Buhranı deneyimleyecektir. Böylesi bir atmosferde, genel çerçevede ekonomik, özelde ise coğrafi kriz ortamında, kruvazörün, 1928 yllında yaptığı planını ertelemeden Türkiye’ye gelişinin, Türk Alman ilişkilerinin geliştirilmesi, iyileştirilmesi ve sağlamlaştırılması için seçilen bir yol olduğu tahmin edilmektedir.

1929 yılında Emden'in Türkiye'ye gelişiyle ilgili daha önce yapılmış hiçbir akademik çalışmaya rastlanmamıştır. Bu çalışmayla literatürdeki bu boşluğun giderileceği düşünülmektedir. Diğer yandan, bu ziyaretle ilgili devlet arşivlerinde de herhangi bir belgeye ulaşılamamıştur. Bu sebeple, dönemin Türk basınına başvurulmuş, kruvazörün İstanbul'a geldiği Şubat 1929 sayıları tamamen taranmıstır. Böylece, Emden kruvazörünün Türkiye’ye gelişi ve İstanbul'da kaldığ1 süredeki faaliyetleri tespit edilmiştir.

Neticede, geminin gelişinin, I. Dünya Savaşı sonunda rafa kaldırılan, fakat Türkiye Cumhuriyeti’nin ilanıyla birlikte canlanan Türk Alman ilişkilerini iyice pekiştirdiği ve iki ülke arasındaki güveni iyice sağlamlaştırdığ tespit edilmiş ve ziyaretin amacına ulaştı̆ı görülmüştür.

Anahtar Kelimeler: Emden Kruvazörü, 1929 Kış Mevsimi, Alman Kruvazörü, Türk Basını.

\section{Port of Call, Turkish Republic During World Tour: Emden Cruiser in İstanbul}

\section{ABSTRACT}

This study is about the Emden cruiser which is the first light cruiser Germany built after World War I that anchored in İstanbul during its world tour.

Year 1929 is important for both İstanbul and world. Winter of 1929 took its place in history as one of the harshest winters of all time. Same year, the world was trying to deal with a huge economic crysis known as Great Depression. The cruisers trip to Turkey without altering its original 1928 plan during a hard time like this is considered as an act of favor to improve, repair and solidify the Turkish-German relations.

No academic researches were found about the Emden cruiser which came to Turkey in 1929. This study fills this gap in literature. On the other hand, no documents were found in national archives about this visit. To find information, the Turkish newspapers of February 1929 issues have been browsed completely. Thus, information about the ship's visit to İstanbul and activities during its stay have been acquired.

As a result, we can say that the ships trip to Turkey fixed and solidifed the Turkish-German relations which came to a pause after the World War I and served its purpose.

Keywords: Emden Cruiser, 1929 Winter, German Cruiser, Turkish Press.

\section{Giriş}

Bu çalışma, İstanbul'daki kara kış ve dünyadaki büyük ekonomik krizin bir araya geldiği olumsuz atmosferde, 1929 yllında, Türkiye'yi ziyaret eden Emden gemisi ile ilgilidir. Emden, I. Dünya Savaşından (1914-1918) sonra Almanya'nın ilk inşa ettiği savaş gemisi/kruvazör olma ve savaş sonrasında Türkiye'yi ziyaret eden ilk Alman gemisi olma özelliklerini bir arada taşımaktadır. Çalışmanın amacı, 1929 yllının atmosferinde gerçekleşen bu önemli ziyaretin sebebi ve sonuçlarına ulaşmaktır. Bunun için, dönemin Türk basınından istifade edilmiştir. Yöntem olarak basın taramasının tercih edilme sebebi, Emden'in 1929 ziyaretiyle ilgili arşivlerde herhangi bir belgeye ulaşılamamasıdır. Bu sebeple; Akşam, Cumburiyet, İkdam, Milliyet, Son Saat ve Vakit gazetelerinin 1929 Şubat sayılarının tamamı okunmuş ve neredeyse ayın başından, kruvazörün geri dönüş tarihine kadar her gün, konunun basına yansıdığı görülmüştür. ${ }^{1}$ Kruvazörün basında bu kadar geniş yer alması, hatta zaman zaman manşetten verilmesi, konuya olan

\footnotetext{
* Dr. Öğr. Üyesi, Başkent Üniversitesi, elifevrim@baskent.edu.tr.

Makalenin Gönderim Tarihi: 14.07.2020; Makalenin Kabul Tarihi: 09.12.2020

1 İdeal olan, Emden'in bir Alman gemisi olması sebebiyle, Alman basınına da başvuru yapılmasıdır. Fakat, yazarın Almancaya hâkim olmaması sebebiyle çalışmanın bu yönünün eksik kaldığı bilinmektedir.
} 
ilgimizi artırmış; gazetelerden elde edilen verilerle Emden'in İstanbul'da geçirdiği süreçteki etkinliklerine de ulaşılmıştır. Tezimiz, tarihi çok eskiye dayanan Türk Alman ilişkilerinin, o dönemin şartlan içinde daha da geliştirilmesi ve Türk Alman dostluğunun sağlamlığının uluslararası platformda gösterilmesi için ziyaretin gerçekleştirdiği yönündedir.

Tarihe adını yazdırmış Alman bandıralı beş ayrı Emden gemisi olduğu bilinmektedir. Birincisi 1759 yılında inşa edilmiş; 1761'de satılmıştır. İkincisi, SMS Emden (His Majesty's Ship Emden) olarak adlandırılan Alman Donanması kruvazörüdür. 1908'de denize indirilmiş, 1909'da donanmada yerini almıştır. I. Dünya Savaşı ve sonrasında aktif çalışmış, 1950'de parçalanmıştır. 1916 yllında inşa edilen hafif zırhlı kruvazör olan üçüncü Emden, 1926'da parçalanmış; dördüncü Emden ise 1925'te hafif kruvazör olarak denizle tanışmıştr. Bu kruvazör 1945'te batırıldıktan sonra, Federal Almanya donanmasına 1959'da dahil edilen yeni firkateyn, tarihe geçen beşinci Emden olarak sıralamada yerini almıştır (Aykun ve Yeşilyurt, 2015; 95-96). Bu sıralamaya göre, 1929 yilında Türkiye'yi ziyaret eden Emden’in, dördüncü olduğu görülmektedir. Fakat, basında çıkan haberlere göre, Türkiye’ye gelen Emden, dördüncü değil, üçüncü Emden'dir. Basın, birinci Emden'in I. Dünya Savaşında savaşan meşhur gemi olduğunu; ikinci Emden'in savaşın son yılında inşa edilen bir kruvazör olduğunu ve batırlldığını; üçüncü Emden'in ise İstanbul'a gelen 1925 yapımı ilk yeni Alman kruvazörü olduğunu yazmaktadır (Cumburiyet, 11 Şubat 1929; 4). Bu geminin üçüncü Emden olduğu başka gazetelerde de yer almıș, ilk iki Emden'in bașından geçenler de aynı yazılarda paylaşılmıştır. En popüler Emden olan birincisinin hatırasına hürmeten verilen "demir salip nişanı" ise Türkiye'ye gelen Emden'de muhafaza edilmektedir. Bu geminin süvarisi ise, savaşlarda batırdığ gemiler sebebiyle kırdığı rekorlar sonucu "Akdeniz Kralı" unvanını almıs, en az geminin kendisi kadar meşhur olan bir denizci olacaktır (İkdam, 12 Şubat 1929, s. 2).

Üçüncü veya dördüncü Emden olmasının önemini bir kenara bırakarak, 1929 yllına kadar hiçbir Emden gemisinin önce Osmanlı, sonra Türkiye Cumhuriyeti karasularına demir atmadığı söylenebilir. Fakat, SMS Emden olarak adlandırlan geminin sadece mürettebatının, I. Dünya Savaşı sürerken, 1915'te Osmanlı'ya sığındığı bilinmektedir. Bu gemi, 1914'te batırılmış, fakat mürettebatın bir kısmı kurtulmuştur. Kurtulanların sığınacağı tek güvenli toprak ise müttefikleri Osmanlı'dır. Epey bir uğraşı sonunda mürettebat, Hicaz demiryolunu kullanarak Osmanlı topraklarına ulaşmış ve her istasyonda törenle karşılanmışlardır. Özellikle 23 Mayıs 1915'te İstanbul'a varmalarından önce yol boyu her durakta, İzmit, Pendik ve Haydarpaşa istikametinde, kendilerine karşılama törenleri düzenlenmiştir. En gösterişli tören ise Sarayburnu'nda gerçekleşmiştir (Üzen, 2010; 361, ss. 372-373). On dört yıl sonra bir başka Emden, bu kez İstanbul'da törenle karşılanacaktır. Bu tören hazırlanadursun hem İstanbul hem dünya o sıralar çok zor bir dönemden geçmektedir.

\section{2. İstanbul'un 1929'u “Kara Kış"; Dünya'nın 1929'u “Büyük Buhran”.}

Emden, seyahat planını 30 Ağustos 1928'de yapmış; Şubat 1929'da İstanbul'a geleceğini Türkiye’ye önceden bildirmişti. Türk hükümeti ise kruvazörün ziyaretini kabul ettiğini, 24 Aralık 1928'de cevap olarak kendilerine iletmişti (Koçak, 2013). Her ne kadar bu plan önceden yapıldıysa da 1929 kış mevsiminin nasıl geçeceği önceden tahmin edilemezdi. O yll kış mevsimi İstanbul'da daha önce pek rastlanmamış sertlikte gelmiști. Cengiz Kahraman bu kıșı, "bir şehir efsanesi” olarak adlandırmışı (Kahraman, 2007).

İstanbul'da 29 Ocak'ta başlayan firtına ve beraberindeki kar yağışı, üç dört gün geçmiş olmasına rağmen durmadan devam ediyordu. Öyle ki daha şubat ayının başında deniz seferleri sekteye uğramaya başlamıştı. Bozcaada etrafinda firtnaya kapilan vapurlar, ancak gecikmeli olarak yerlerine varıyordu. Fakat Karadeniz'den gelen vapurlar yerlerine ulaşmıyorlardı (İkdam, 2 Şubat 1929; 1). Daha şubatın ikisinde, kar tipisi günlük hayatı nerdeyse durma noktasına getirmişti. Vapurlar ve tramvaylar yollarına devam edemez olmuş; çıkan firtına sebebiyle yol kenarlarında kar yığınları oluşmuştu. Rüzgâr bu kar birikintilerini yerinden oynatmış, bu sebeple geniş caddelerin sonları gözle görülmeyecek bir hal almıştı. Vapur seferleri, başta Kadıköy-Adalar hattı olmak üzere, ay başında iptal oldu. Açık denizdeki firtınanın ise daha şiddetli olduğu haberleri gelmişti. 2 Şubat 1929'da Zonguldak'tan kalkmış olan vapurdan haber alınamıyor; vapurun Rusya'ya doğru savrulduğu düşünülüyordu. İstanbul'dan İzmir'e giden bir gemi ise Gelibolu'da yolda kalmıştı. Mudanya'dan İstanbul'a gelmekte olan diğer bir vapur da yolda kaybolmuştu. Boğaz dışından bir imdat işareti alınıyordu fakat vapurun yeri ve kimliği tespit edilemiyordu. Kayıp bir başka vapurun Sinop'a yaklaşmış olması gerekiyordu fakat bu, sadece tahminden ibaretti. Anadolu ve Avrupa 
yakalarının telgraf haberleşmesi firtına sebebiyle kesilmişti. Ancak Ankara'ya geç de olsa telgraf gönderilebiliyordu. Trenler işleyemiyor; bu sebeple mektuplar yerlerine ulaşmiyordu. Yollarda kalan arabaların kurtarılması için belediye işçileri görevlendirse de 3 Şubat günü öğle saatlerinde başlayan tipi, işçilerin çalışmasına müsaade etmemişti. Bu durum sadece İstanbul için geçerli değildi. Örneğin, Zonguldak-Devrek yolu tam bir haftadır kapalıydı. Okullar iki gün tatil edilmişti. Üç gündür devam eden poyraz ise İmir'i vuruyordu (Cumburiyet, 3 Şubat 1929, s. 1, 2).

4 Şubat, kar firtınasının İstanbul'u kasıp kavurduğunun haberinin geldiği gündü. İstanbul'da musluklar donmuştu. Batan vapurların yanı sıra insanlar sokaklarda donarak ölmekteydi. Gemiler limanlarda bekliyor, trenler yollarda kaliyordu. Karadeniz'de bir Rus vapuru karaya oturmuştu. Diğer vapurlar ise limanlara yanaşamıordu. Meteoroloji ise firtınanın devam edeceğini söylüyordu. Bu sebeple esnaf, dükkanlarını açamıyordu. Yeşilköy ve Bostancı civarına kurt indiği haberi ise gecikmemişti. Hatta habere göre bir kurt, bir sütçüye saldırmıştı. Binaların kiremitleri uçmuş, camlanı kırılmıştı. Un dağıtımı yapılamıyor, firınlar açılmıyordu. Fakat ekmek gerekiyordu. Bu sebeple belediye; un, ekmek ve para dağıtıma başlamışı (Cumburiyet, 4 Şubat 1929; 1, 4). 4 Şubat tarihinin bilançosu ulaşımın durduğu, dükkânların kapalı olduğu, ekmek sevkiyatının yapılmadığı, Çerkes köyünde üç trenin kar alında kaldığı ve Adalar'da bir vapurun battığı şeklinde özetlenebilirdi. Soğuktan altı kişi donmuştu. Denizde kazalar oluyor; uzun zamandır haber alınmayan bazı gemilerin karaya oturduğu haberi geliyordu. Karaya oturmuş bir vapurda ağır yaralılar olduğu haberi gelmişti. Vapurun süvarisi telsizle ekmek ve su istiyordu (İkdam, 4 Şubat 1929; 1). Aynı gece hava sıcaklığ1 -10 derece olarak ölçüldü. Sadece dükkânlar değil, cami, kilise ve okul gibi her türlü kurum kapandı. Erenköy halkı dışarı çıkamadığı için o bölgeye özel yardım götürüldü (İkdam, 5 Şubat 1929, s. 1).

Kar firtınası tam üç gün devam etti. 6 Şubat'ta Çatalca'da kar altından cesetler çıkarılmaya başlanmıştı. $\mathrm{Bu}$ arada Karadeniz'de bir Rus vapurunun kaza yaptığı ve mürettebatının yaralandığı bilgisi de geldi (İkdam, 6 Şubat 1929; 1). Demiryolları karla kaplanmış, halk ekmeksiz kalmış, et nakli yapilamamış, elektrik ve sular kesilmiş, ulaşım imkânsız hale gelmişti. Halk içme suyu bulamayınca kar suyu içmeye başlamıştı. Cenazeler ise evlerde bekletiliyordu (Cumburiyet, 8 Şubat 1929, s. 1). Bu sırada Beyoğlu ve Taksim'den karlar toplanmaya ve meydanlara yığılmaya başlandı. Meydanlarda adeta kar tepeleri oluşmuştu. Boğaziçi ve Tarlabaşı yolu tamamen kapanmıştı. Deniz kazaları haberlerinin ardı arkası kesilmiyordu (İkdam, 8 Şubat 1929, s. 1).

Kar yağışı, 9 Şubat'ta bir nebze de olsa durmuş̧tu fakat bu, arkasından ayazı getirdi. Bu ayazın Haliç̧i donduracağı haberleri kulaktan kulağa yaylliyordu. Sıcaklık -12 derece olarak ölçülmüştü. İstinye'de deniz, çoktan 3-4 cm kalınlığında buza dönmüştü. Trenler yola çıkamıyor, vapurlardan haber alınamıyordu. Yirmi yıldır İstanbul'da böyle sert bir hava durumu görülmüyordu. Sadece yurtiçi değil, Avrupa'dan gelen posta trenleri de çalışmıyordu. Hollanda bandıralı bir vapur hareket etmeye cesaret etmişti; fakat birinci çarkçısı düşüp ayağını kırınca geri dönmek zorunda kaldı. Gözlerini karartıp yola çıkan Rus vapurları ise bir yere kadar gidebilmişler; o yerde mahsur kalmışlardı (Cumburiyet, 9 Şubat 1929, s. 1). Bir başka gazete, aynı gün İstanbul'da sıcaklı̆̆ın -13 olduğunu haber yaptı. Belli ki Haliç gerçekten donacaktı. Bu sebeple buharlı gemiler, borularının patlamaması için ayrı bir yere alındı. Şehirde sekiz yüzden fazla elektrik feneri bozuldu. 150 koyunun donma haberi de çoktan gelmişti (İkdam, 9 Şubat 1929, s. 1, 3). Bütün bu haberlerle birlikte beklenen oldu. Haliç vapurları, buz tutan iki sahil arasında sıkışıp kaldılar. Zira termometre -20'yi göstermişti. Moda ve Bebek koyları donmuştu (İkdam, 10 Şubat 1929, s. 1).

Emden'in İstanbul'a yanaşacağı gün olan 11 Şubat sabahı, İstanbul halkı yeni bir kar yağışına uyandı. Üstelik nezle salgını şehri kaplamıştı. Göksu, Kağgthane ve Kurbağalı Dereleri tamamen donmuştu (İkdam, 11 Şubat 1929, s. 1). Soğukların devam ettiği, etlerin ancak testereyle kesilebildiği haberiyle vurgulanıyordu. Yollarda donan insanlara rast geliniyor, bazı kişiler son anda donmaktan kurtarıllyordu. Diğer yandan belediye, Haliç'e, buzların kırılması için işçiler göndermiş; bu sayede limanda vapur seferleri başlamıştı. Ada seferleri yapılıyor fakat diğer seferler sekteye uğruyordu. Açık denizlere kar yağmıştı. İtalyan bandıralı bir vapur o gün Köstence'de karaya oturmuştu (Cumburiyet, 11 Şubat 1929, s. 5). Unkapanı'nda kayıklar buzlar arasında kalmıştı. Takip eden gece kar yine başlamış, açlışs yollar yine kapanmıştı. Kadıköy'de dereler 10 santim buz tutmuştu. Boğazda kar tipisi şiddetle devam ediyordu (Cumburiyet, 12 Şubat 1929, s. 2). 
Şubat ayının on üçüncü günü, kar firtınası dinip rüzgâr başlayınca, karlar erimeye başladı. Bu kez sokaklar çağlayan derelere döndü. Vapurlar yine gece seferlerini yapamadı. Posta vapurları ise zor şartlarda seferlerini tamamlayabildiler. Binalar çökmeye başladı, arabalar ise çöken binaların altında kaldılar (Cumburiyet, 13 Şubat 1929, s. 1, 3). Ayın ortasında ise havalar biraz düzelmeye başladı. Tramvaylar tekrar sefere başladılar fakat bu kez borular patlamaya başladı. Limanlarda ise sis vardı; fakat vapurlar seferlerine başliyorlardı (Cumburiyet, 14 Şubat 1929, s. 1).

Özetle, ay başında yağan yoğun kar ve tipi sebebiyle günlük yaşam olumsuz etkilenmişti. Özellikle deniz yolunun kapanmış olması ve denizden gelen kaza haberleri, Emden için problem teşkil etmekteydi. Daha şubatın ikisinde Akdeniz ve Karadeniz'deki tipi sebebiyle denizlerin karıştı̆̆ı, Karadeniz'den neredeyse hiç vapurun gelmediği, İzmir'den gelen vapurların altı saat açık denizde beklediği duyulmuştu (Milliyet, 2 Şubat 1929, s. 1). Ertesi gün üç vapur kaybolmuş, bir vapur batmıştı. Karadeniz'den yola çıkmış vapurların Samsun, İnebolu ve Sinop'ta beklediği ve Dedeağaç'ta bir vapurun battı̆̆, denizlerden gelen haberlerdi. Köprüler kapalıydı ve şehir içi vapur hatları iptal edilmişti (Milliyet, 3 Şubat 1929, s. 1). Ertesi gün vapur seferleri hâlâ başlayamamıştı. Akdeniz ve Karadeniz'e sefer yapılması zaten imkânsızdı (Milliyet, 4 Şubat 1929, s. 1). Takip eden gün, Adalar, Bakırköy ve Bostancı'ya ancak un sevkiyatı yapılabildi. Diğer yandan, Köstence'den bir vapur sonunda İstanbul'a ulaşabilmişti (Milliyet, 5 Şubat 1929, s. 1). 8 Şubat'ta Karadeniz'den iki vapur da İstanbul'a ulaşmıştı. (Milliyet, 8 Şubat 1929, s. 1). Fakat hemen ertesi gün, Karadeniz'de yine bir firtına çıtı. Haliç'in yine buz tutacağı aşikardı. Düzenli olmasa da vapur seferleri başlatılacaktı (Milliyet, 9 Şubat 1929, s. 1). Emden’in geldiği gün, liman şirketlerinin buzları kırdırarak bir geçit açtırdığı haberi geldi. Fakat gece yine bir vapur batmışt (Milliyet, 11 Şubat 1929, s. 1). Şubat ayında denizlerdeki durum böyleydi.

İstanbul bu haldeyken dünya da aynı soğuğu yaşıyordu. Emden'in memleketi Almanya'da termometre eksi 22 dereceyi gösteriyordu. Rusya, Almanya, Avusturya ve Romanya bu soğuktan epey etkilenmişti (Cumburiyet, 9 Şubat 1929, s. 3). Almanya'ya soğuk havanın Rusya'dan geldiği söyleniyordu. Berlin donuyordu (İkdam, 4 Şubat 1929, s. 2). Kopenhag'n dünyayla bütün ilişkisi kesilmişti. İngiltere'de sert soğuklar devam ediyordu. İsviçre'de göller donmuş, Balkanlarda kurt sürüleri etrafa yayılmıştı. Çekoslovakya'da toprağın sertliği sebebiyle ölüler gömülemiyor, Macaristan'da dişarıda yaşayan insanlar donmamak için hapishaneye girmeye çalışıyorlardı (İkdam, 13 Şubat 1929, s. 1). Hava soğukluğu ve kar tipileri bir yana, dünyada çok büyük bir ekonomik krizin ayak sesleri de duyulmaya başlanmıştı.

Dünya, bir yandan bu sert kışla baş etmeye çalışırken; diğer yandan Büyük Buhran olarak adlandırılacak büyük bir ekonomik krizin içine sürükleniyordu. Emden, Şubat 1929'da İstanbul'a gelmişti. Kriz ise 24 Ekim 1929'da patlak verecekti. Şubat ayında, yaklaşık sekiz ay sonra gün yüzüne çıacak küresel bir krizin ayak seslerinin duyulmuyor olması mümkün değildi. I. Dünya Savaşından Versailles (Versay) Antlaşması (1920) gibi kendisini yıkıma götüren, topraklarını kaybettiren, silahlanma ve haberleşme haklarının elinden alındığ1 ve konumuz kapsamında deniz kuvvetlerinin sınırlandırıldığ1 (Gürün, 1986, ss. 93-95) bir belgeyle çıkan Almanya'nın, bu krizden etkilenmemesi pek de mümkün değildi. Bilindiği üzere kriz ABD'de başlayacak, en büyük sarsıntılarını ve etkilerini İngiltere, Fransa ve Almanya'da gösterecekti. Bu dört ülke içinde bir tek Almanya savaştan başarısız çıkmıştı. Üstelik 1920’lerin sonunda ekonomik sıkıntılar, başta belediye giderlerinde olmak üzere Almanya'da kendini gösteremeye başlamışı (Temin, 2010, s. 4). 1923 yılında yaşadığ hiperenflasyon ise ekonomisinin iyice çökmesine sebep olmuştu (Eichengreen, 2015, ss. 36, 42).

Almanya, ön gördüğü krizden az zararla çıkmak için, edindiği tecrübelerden ders alarak, diğer ülkelerle olan ilişkilerini güçlendirmeliydi. Bu ülkeler içinde eski müttefik Türkiye de olmalıydı. Üstelik, I. Dünya Savaşı'ndan Osmanlı İmparatorluğu ve Almanya adeta birer idam fermanı olan iki antlaşmayla çıkmıştı. Almanya'nın Versay'ı, Osmanlı'nın Sevr'i (1920) idi. Fakat Almanya'dan farklı olarak Türkiye, Millî Mücadele'yi (1919-1922) başantıla sonuçlandırmış ve Türkiye Cumhuriyeti (1923) devletler sahnesine çıkmışt. Diğer bir ifadeyle Türkiye, Lozan Barış Antlaşmasını (1923) imzalayarak Sevr’i yok saymıştı. İlaveten, 1929 yllına kadar epey bir yol kat etmişti. Cumhuriyet ilan edilmiş (1923), ekonomik bağımlılıklar reddedilmiş ve Türkiye İktisat Kongresi gerçekleşmişti (1923). Halifelik kaldırılmış (1924), Şeyh Sait İsyanı (1925) gibi ayaklanmalar bastırlmış, şapka tanıtılmış (1925), Harf Devrimi (1928) yapılmıştı. Bütün bu yeniliklerin dünyaya tanıtılması için sabit sergiler (1929) ve yüzer fuarların (1926) düzenlenmesine devam 
ediliyordu. Uluslararası fuarlar için ise henüz zaman vardı. Çünkü, sosyal ve siyasi hayatta yenilikler henüz tamamlanmamıştı. Diğer bir ifadeyle, Almanya'nın eski müttefiki Türkiye, küllerinden yeniden doğmuş, bu "rönesansı" dünyaya tanıtmaya başlamış ve bu tanıtımda ülkeler arası ilişkileri güçlendirmek hedeflenmişti.

Almanya ise bu süreçte yeni bir krize sürükleniyordu. Krizi atlatabilmek için ekonomisini güçlendirmeli, diş ülkelerle ilişkililerini sıcak ve sağlam tutmalıydı. Bunun için birçok yol vardı. Bu yollardan biri ise dostluk ziyaretleriydi. İşte Yeni Emden'in dünya turuna çıkma sebeplerinden biri buydu. Böylesi bir atmosferde, Emden, devrialem kapsamında, eski dost Türkiye'yi de gezi planına dahil etmişti. Çünkü, 1918 sonrası antlaşma maddeleriyle durdurulan Türk Alman ilişkileri, Türkiye Cumhuriyeti'nin ilanıyla tekrar hareketlenmeye başlamıştı. Şimdi bu hareketlendirmeyi taçlandırmak gerekiyordu. Diğer bir ifadeyle, "Kara Kış" ve patlamaya az zamanı kalmış "Büyük Buhran”, Emden'in Türkiye planını iptal ettiremediği gibi, ertelettirememişti.

\section{Emden Geliyor}

Emden, Almanların I. Dünya Savaşından sonra inşa ettiği ilk savaş kruvazörüydü. Gemiye bu ismin verilmesinin, savaştaki "kahraman" Emden'le ilgisi olduğu aşikârdı. Yeni Emden 15,5 metre uzunluğunda, 14,3 metre genişliğinde, su kesiminin 5,3 metre olduğu, 6000 tonluk bir gemiydi. 8 topu, 8 projektörü hem kömür hem mazot kazanı vardı. Sadece Türk basını değil, İngiliz ve Fransız basını da Emden'in son teknolojiye uygun yapıldığını yazmıştı. Sınıfının tek savaş gemisi olduğu gibi, uzun seyahatler yapabilen, savaştan alınan ders ve tecrübelerle inşa edilmiş son sistem bir gemiydi (Koçak, 2013; Cumburiyet, 11 Şubat 1929, s. 4). Versay Antlaşması, Almanlara 6000 tondan büyük kruvazör yapmayı yasaklamıştı. Emden ise tam 6000 tondu. Antlaşma kuralları çiğnenmeden yapılmış, Alman Donanmasına ait çağının en modern gemisi olarak 1925’te denizlere açılmışt. II. Dünya Savaşından (1939-1945) önce ise eğitim gemisi olarak kullanılacaktı (Koçak, 2013).

Alman bandıralı Emden kruvazörünün 11 Şubat 1929 Pazartesi günü, önceden yaptığ1 planını aksatmadan İstanbul limanına geleceği, 1 Şubat 1929'da Türk Deniz Ticareti müdüriyetine bildirilmişti. Kruvazörün merasimle karşılanması gerekmekteydi (Cumburiyet, 1 Şubat 1929, s. 1). Zira Türk hükümeti, Almanya'nın kendi donanmasındaki bu tanınmış gemiyi Türkiye'ye göndermesinin anlamını takdir edeceğini önceden ifade etmişti (Koçak, 2013). Geminin sabah saat 08.00'de limana gelmesi planlanıyordu. Alınan bu ilk haberle merasim planı yapılmaya başlandı. Gemi, limana yaklaşırken top atarak şehri, özelinde Selimiye'yi, selamlayacak; Selimiye'den de karşılık verilecekti. Aynı gün saat 10.00 'da geminin süvarisi, vali ve kolordu kumandanını ziyaret edecekti. Bu ziyaretin iadesi de planlanmıştı. Süvarinin, ayrıca Ankara'y1 ziyaret etme isteği de iletilmişti. Bu ihtimal dahilinde, Ankara'da büyükelçilikte bir ziyafet verilmesi gündeme geldi (Cumburiyet, 3 Şubat 1929, s. 2).

Emden'in Türkiye'deki ziyaret programı ve saatlerinin henüz kesinleşmediği belliydi. Zira, alınan başka bilgiye göre süvari, saat 10.00 'da değil 11.00 'de valiyi, 12.00 'de ise kolordu ve donanma komutanın ziyaret edecekti. İade-i ziyaretler ise aynı gün öğleden sonra gerçekleşecekti. Bir sonraki gün, 12 Şubat’ta, gemideki Alman deniz harp okulu öğrencileri, İstanbul'daki Deniz Harp Okulunu ve şehri gezeceklerdi (Milliyet, 3 Şubat 1929, s. 3). Versay Antlaşması gereği mesleklerini icra edemeyen Alman subayların bir kısmı İstanbul'da Yıldız Harp Akademisinde eğitmen olarak görev yapmıştı. Buna karşlık bazı Türk subayları da Almanya'ya eğitime gitmişti (Koçak, 2013). Bu kapsamda, Emden'in öğrencilerinin, Türkiye'deki bir harp okulunu gezmek istemeleri olağandı. Bu, aday subaylar arasındaki ilişkileri güçlendirecek önemli bir adımdi.

Planlar her ne kadar henüz netleşmese de kruvazörün ayın 11'inde geleceği belliydi. Geminin İstanbul'a, varış saatinin sabah 08.00 olduğunun kesinleştiği bilgisi gelmişti. Selimiye'ye yapılacak merasimin ayrıntıları da yavaş yavaş belli oluyordu. Örneğin, kruvazörden 21 pare top atılacağı kesinleşmişti. Süvarinin valiyi ziyaret saati ise 11.00 olacak gibi görünüyordu. İade-i ziyaretin ise öğleden sonra gemide yapılması kararlaştırılmıştı. Alman denizcileri valiyi gemide karşılamak istemişlerdi. Ertesi gün gemideki öğrencilerin Heybeliada Deniz Harp Okulunu ziyaret edecekleri de yine kesinleşen bilgiler arasındaydı (İkdam, 4 Şubat 1929, s. 2). Bu arada, Alman büyükelçisi Bay Rudolf Nadolny'nin ise 4 Şubat'ta Ankara'dan İstanbul'a gelmesi kararlaştırılmışı. Büyükelçi, Emden'in resmi kabulünde bizzat bulunmak istiyordu (Son Saat, 4 Şubat 1929, s. 2). Zira Nadolny, diplomat olmanın yanı sıra, I. Dünya Savaşında görev almış bir subaydı. Kendisi aynı zamanda Almanya'nın ilk Ankara büyükelçisiydi (Bütüner, 2015 ss. 266-269). 
Emden'in geliş tarihi yaklaştıkça, kruvazörle ile ilgili yapılan planlar günden güne güncelleniyordu. Fakat diğer yandan farklı bir tesadüf söz konusu olmuştu. Bilindiği üzere Emden, Almanya'da bir şehir ismiydi ve bu şehre ait bir de futbol takımı vardı. Geminin İstanbul'a gelişinden dört gün sonra, 15 Şubat'ta, Emden futbol takımıyla İstanbul'da bir maç yapılması teklif edilmişti. Cevabın olumlu olması bekleniyordu (İkdam, 7 Şubat 1929, s. 5). Bu maç yine, ikili ilişkileri kuvvetlendirecek önemli bir adımdı.

Emden'in İstanbul'da 4-5 gün limanda kalacağı belirlenmişti. Merasim ve ziyaret programı ise 7 Şubat itibariyle, Dışişleri Bakanlığında görevli bir deniz subayı ve Alman Büyükelçiliği arasındaki görüşmeler sonucu son halini almaya başlamıstı (Cumburiyet, 8 Şubat 1929, s. 4). Aynı gün, kruvazörün 11 Şubat 1929 günü saat 08.00 'de İstanbul'a yanaşacağı, bu kez resmî olarak bildirilmişti. Alman elçiliği özel kalemi ve Deniz Kuvvetlerinden Hakkı Bey’in onaylarıla merasim ve ziyaret programı tamamlanmıştı. Kruvazörün İstanbul'da tam beş gün kalacağı ise kesinleşmişti. Komutanlıkta, Alman denizcilerine bir ziyafet verilmesi de planlara dahil edilmişti. Selamlama esnasında topların atılması da resmiyet kazandı. Diğer yandan, Emden'in karşılanması için bir Türk kruvazörü olan Mecidiye, Haliç’ten çıkarıldı. Mecidiye, 9 Şubat günü Çanakkale'ye hareket edecek, boğazda Emden'i karşılayacak, Çanakkale'den İstanbul'a kadar da gemiye refakat edecekti (İkdam, 8 Şubat 1929, s. 1). Emden'in İstanbul'da kaldığı süre boyunca yapacağ ziyaret ve verilecek ziyafet programı 7 Şubat itibariyle neredeyse kesinleşmiş gibiydi. (Milliyet, 8 Şubat 1929, s. 1).

Programa göre Emden'in süvarisinin Ankara'ya ziyareti de kesinleşmişti. Kesinleşen diğer program maddeleri şunlardı: Kruvazör, 11 Şubat saat 08.00'de Haydarpaşa önünde top atarak memleketi selamlamasının ardından Boğaziçi’nde bir tur atacak, ardından Dolmabahçe'ye demirleyecekti. Bu durumda, Selimiye'yi selamlaması iptal edilmiş görünüyordu. Süvari saat 11.00 'de valiyi, saat 12.00 'de üçüncü kolordu komutanını, 12.30'da ise donanma kumandanını ziyaret edecekti. 12 Şubat Salı günü, 66 Alman deniz harp okulu öğrencisi, saat 14.00-17.00 arası Deniz Harp Okulunu ziyaret edecek ve orada çay içeceklerdi. Aynı akşam saat 20.00 'de Mecidiye gemisinde Emden süvarisi ve subaylanı şerefine ziyafet verilecekti. Gemideki 12 subay bu ziyafete katılabilecekti. Toplamda 40 kişinin ziyafete kattlması planlanmıştı. Türk donanmasından subaylar ise takip eden günlerde Emden'i ziyaret edecekti. Diğer yandan, Emden'de danslı bir gösteri yapılmasına karar verilmişti. Ardından Ankara'ya gidilecekti. Bu sebeple, Ankara'daki elçilikte bir balo tertiplenmesi için hareketlenme başlamıştı (Cumburiyet, 9 Şubat 1929, s. 4; Milliyet, 9 Şubat 1929, s. 3).

Yukanda işaret edilen futbol maçı ise hâlâ gündemdeydi. Takımın 12 Şubat'ta, yani geminin gelişinden bir gün sonra, İstanbul'da olacağı haberi de gelmişti. Gemiyle aynı tarihlerde Emden futbol takımının da İstanbul'da olması güzel bir tesadüftü. Hava durumu maç için pek uygun olmasa da hazırlıklı olunması gerekiyordu. Basına bu haber, Emden'in yapacağı maçın, propaganda amacı taşıdığ şeklinde yansıdı (İkdam, 9 Şubat 1929, s. 5).

Artık kruvazörün gelişi yaklaşıyordu. Fakat bütün memleket karla kaplıydı. Aynı gün kar yağışının devam edeceği meteoroloji tarafından bildirilmişti. Deniz ulaşımının ise olması gerektiği gibi işleyemeyeceği de belliydi (Cumburiyet, 11 Şubat 1929, s. 2). Yukanda işaret edildiği gibi o gün Haliç’teki buzların kırdırılması işlemi başlamıştı. Birçok vapurun kayıp ya da karaya oturma haberleri gelirken, son teknoloji savaş gemisi Emden, hava koşullarının zorlamasına karşın, 11 Şubat 1929'da İstanbul'a geldi. O gün Ramazan ayının ilk günüydü.

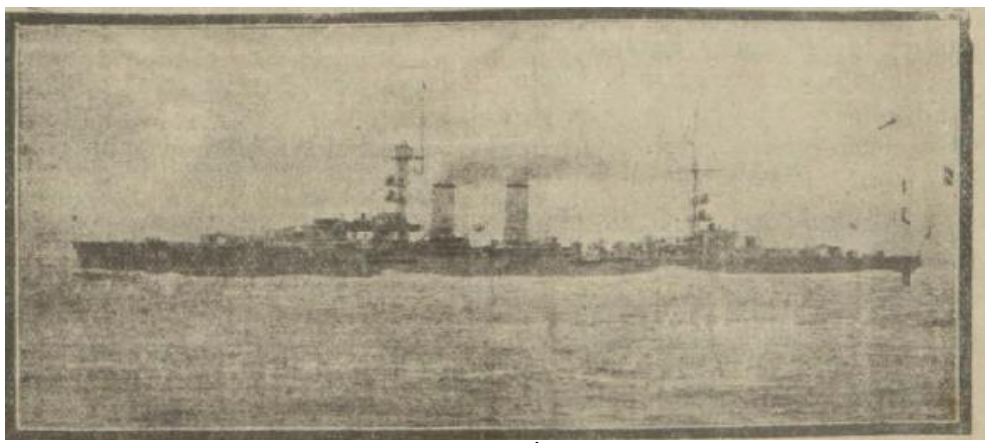

Resim 1. Emden Kruvazörü (İkdam, 13 Şubat 1929, s. 1). 


\section{Emden'in İstanbul'daki Beş Günü}

Türkiye'nin Emden ismine yabancı olmadığı, geliş gününün gazetelerine yansımıștı. Almanların bu gemiyi yeniden inşa etmesinin sebebi I. Dünya Savaşı'ndaki Emden'in kahramanllğıydı. Diğger bir ifadeyle bu ismin yaşatulması için yeniden bir Emden inşa edilmişti. Emden’in, isminin şanıyla devrialemdeki duraklarından biri olan İtalya'ya demirlediğinde, Napoli limanında çok büyük bir merasimle karşılandığı basında yer almıştı. Bu sebeple Türkiye'deki merasim sönük geçmemeliydi. Çanakkale'den geçerken gemiye, iki Türk denizcisi ve bir Alman dahil oldu (Milliyet, 11 Şubat 1929, s. 2). Programdaki yeni değişikliklere bağlı kalınacaktı. Emden’in İstanbul'a girişine sadece bir gün kalmıştı.

Gemi, planlandığı gibi 10 Şubat günü saat 13.30 'da Çanakkale'den geçmişti. Süvarisi ise meşhur Alman denizalt kaptanlarnndan, iki rekor sahibi Kumandan Arnauld de la Perière idi. Rekorlannnn birincisi, savaşlarda en çok gemi batıran Alman süvarisi olmasıydı. İkincisi ise, 91bin tonluk bir gemiyi tek seferde batırmış olmasıydı (Cumburiyet, 11 Şubat 1929, s. 4). Emden'in Çanakkale'den geçişinin haberi telgrafla alındıktan sonra, Alman elçiliğinden bir memur Boğaz’a Emden’i karşılamaya gelmişti. Tören planında ise son anda ufak bir değişiklik yapılmıştı. Değişiklik, geminin, ilk plandaki gibi Selimiye'den veya sonradan planlandığı gibi Haydarpaşa'dan değil, Dolmabahçe'den selamlanması yönündeydi (İkdam, 11 Şubat 1929, s. 1). Diğer yandan kar yağışı başlamış, nezle salgı̣ı da şehri sarmıştı.

Yaklaşık iki ay önce Hamburg'dan hareket eden gemi, İspanya, İtalya ve Yunanistan sonrası, 11 Şubat 1929'da 500 mürettebattyla, sabah saatlerinde İstanbul'a girdi. Önceden servis edilen haber gibi saat 08.00'de değil, 09.00 'da limana giriş yaptı. Fakat gelişsiyle ilgili basına yansıyan haberler birbiriyle çelişiyordu. Örneğin Milliyet, 10 Şubat saat 13.30'da geminin Çanakkale'de Türk subayları ve Alman elçilik memurlarından oluşan bir heyet tarafindan karşılandığını; limana girer girmez Selimiye önünde topla karşılama merasimi yapıldığını ve Boğaziçi’ne giderek Dolmabahçe'de demirlediğini yazmıştı (Milliyet, 12 Şubat 1929, s. 1). Oysa merasim planı değişmişti. Emden Dün Sabah Geldi manşetiyle bu gelişi ilk sayfadan haber yapan bir başka gazeteye göre gemi, Selimiye'de değil Haydarpaşa önüne geldiğinde top atılarak şehri selamladı. Boğaziçi’nde dolandı, Dolmabahçe önünde demirledi. Süvarisi, bir motorla Dolmabahçe rıhtımına çıktı ve Alman konsolosluğuna gitti. Öğle yemeğini burada yedi. Süvari, Elçi Nadolny ile vali vekilini, Kolordu Komutanını ve Donanma Komutanını ziyaret etti. Aynı gün öğleden sonra iade-i ziyaretler yapıldı. Planlandığı gibi 12 Şubat gecesi Mecidiye'de misafirler şerefine ziyafet verilecekti. Alman denizcileri, İstanbul'da dostane karşılanmışlardı. Belediye Başkanı ve Valinin Emden'e girerken muhabirler tarafindan fotoğrafları çekilmişti (Cumburiyet, 12 Şubat 1929, s. 1).

Bazı gazetelere durum, Emden Kruvazörü Dün Geldi manşetiyle yansıdı. Pazar gününe kadar İstanbul'da kalacağı, geldiği gün Emden ve Mecidiye'de törenler yapıldı̆̆ı, gemide ziyafetin gerçekleştirildiği ve gemide 66 Alman deniz harp okulu öğrencisinin bulunduğu bilgileri ilk satırlarda yer aldı. Bu manşetin altındaki haberde Emden'in 09.30 'da limana giriş yaptğ̊ yazmaktaydı. Plana göre Emden'i Çanakkale'de, Mecidiye'nin karşılamış olması gerekiyordu. Fakat, Mecidiye Çanakkale'ye gidememiş, Emden'i İstanbul'da limanda beklemişti. Bunun sebebi Marmara'da tipi şeklinde kar yağıyor olmasıydı. Hatta planda bulunan Boğaziçi'ndeki tur kısmı da bu sebeple iptal edilmişti. Tipi şiddetlendiği için Emden dolanma gösterisini yapmamış, doğrudan demir atmıştı. Öyle görünüyordu ki basına servis edilen haberler birbirini tutmamaktaydı. Diğer yandan, hava koşullarına göre planda değişiklikler olmuş olma olasıllğı da yüksekti. $\mathrm{Bu}$ aksamalara rağmen Emden limana girmiş; grandi direğine Türk bayrağını çekmiş ve 21 top atışıyla şehri selamlamıştı. Bu selamlamaya cevap da gecikmemişti. Mecidiye ise ayrıca selamlanmış, aynı şekilde cevap da alınmıştı. Kruvazör demirler demirlemez süvari, saat 10.00 'da rıhtıma çıkmış, ziyaret için Alman konsolosluğuna gitmişti. On beş dakikalık bir ziyaret sonrası sırada kolordu komutanlığ ziyareti vardı. Vali ve komutanlık ziyaretlerinin sonrası Emden'in güvertesinde bir bando gösterisine tanık olundu. Aynı gece, Beyoğlu Totonya Kulübünde, Emden'in süvarisi şerefine bir ziyafet verildi (İkdam, 12 Şubat 1929, ss. 1, 2).

12 Şubat 1929'da İstanbul'a gelişin ertesi günü, öğleden sonra Emden'de bir resmi kabul düzenlenecekti. Akşam ise Dolmabahçe'de demirli Mecidiye'de, Deniz Kuvvetleri tarafindan ziyafet verilecekti. Bu ziyafette hem Türk hem Alman rütbeli askerleri bulunacaktı. 13 Şubat'in planı ise hava koşulları uygun olduğu taktirde Heybeliada Deniz Okuluna gitmekti. Planlar, Türk deniz subaylarının Emden'i ziyareti, Alman konsolosluğunda verilecek balo, süvarinin Ankara'yı ziyareti sıralamasiyla ilerlemekteydi (Cumburiyet, 12 Şubat 1929, ss. 1, 3). Aynı gün, bir başka gazetede plana yeni bir hususun 
daha eklendiği yazmaktaydı. Habere göre, Emden şerefine akşam verilecek ziyafetin yanı sıra Darülbedayi'de müsamere düzenlenecek, perşembe günü ise Tokatlyan Otelinde başka bir ziyafet verilecekti (Milliyet, 12 Şubat 1929, s. 1). Takip eden günler için yapılan bu planlar, hava koşullarına bağlı ilerleyecekti. Geminin geldiği gün derece -5 'i gösteriyordu. Bir sonraki gün ise -8’i. Meteoroloji kar yağışının birkaç gün daha devam edeceğini bildirmişti. Şehirde su buhranı vardı (Son Saat, 12 Şubat 1929, s. 1).

Gerçekten 12 Şubat akşamı kar tipisi devam etti. Bu durum, Emden'deki resmî kabulü aksatmadı. Kabul sonrası geminin içinin gezilmesi plana dahildi. Gemideki deniz harp okulu öğrencilerinin Heybeliada Deniz Harp Okulunu gezme planı da iptal edilmemişti. Okul, çay ziyafetine hazırlanıyordu. Öğrenciler adadayken, Mecidiye'de, üst düzey yetkililer için kırk kişilik ayrı bir ziyafet tertiplendi (Son Saat, 13 Şubat 1929, s. 2). Emden'deki resmi kabulde ise süvari, 35 numaralı denizalttyla I. Dünya Savaşında kırdığ1 rekoru anlatmış ve bu konuşma epey ilgi görmüştü. Bu konuşma sonrasında kruvazörün içi gezildi. Türk Deniz Kuvvetleri Komutanı için Emden'de ayrı özel bir gezi düzenlenmişti (Milliyet, 13 Şubat 1929, s. 1). $\mathrm{Bu}$ resmi kabule Türk, azınlık ve yabancı basının tamamı davet edilmişti. Bu sebeple gazetelerde, bu kabulle ilgili farklı ayrıntılar göze çarpıyordu. Örneğin, yukarıda işaret edilen rekor kırma hatırası anlatılırken, o dönem çekilen fotoğrafların da paylaşıldığı haberi çoğu gazetede yoktu. Hatta bu fotoğraflara, Alman cumhurbaşkanının birinci Emden'e verilmek üzere hazırlattığı, fakat taşıması üçüncü Emden'e nasip olmuş bir fotoğraf da dahildi. Dünya Savaşındaki ittifak sebebiyle olsa gerek, Türk basınının bu fotoğraflara pek yabancı olmadığı da davetliler tarafından dile getirilmişti. Sonrasındaki gemi içi gezisine basın da davet edilmişti. Saat 18.00'de basın için özel bir çay ziyafeti verildi (İkdam, 13 Şubat 1929, s. 2). Bu çay ziyafetine Türk ve Alman gazetecileri, saat 16.30 'da motorla gemiye giderek iştirak etmişlerdi. Başka bir basın mensubundan, hatıraların anlatıldığı sırada gösterilen fotoğraflara ait alınan başka bir bilgi ise şöyleydi. Gemide, birinci Emden'in hem sağlamken hem de İngilizler tarafindan batırıldıktan sonra çekilmiş fotoğrafları mevcuttu. Anlatımlar Almanca gerçekleşiyor, kıdemli Yüzbaşı Necati Bey tarafindan Türkçeye tercüme ediliyordu. Bu anlatım ve gezi sonrası, süvariyle birlikte anı fotoğrafları çekildi. Gazetecilere puro ve Porto şarabı ikram edildi. Bu esnada Heybeliada'da olan öğrencilere ise çay ziyafeti verilmiş, okulun içi gezdirilmişti. Bu durumda mürettebat, bir iki akşam içinde Emden'de, elçilikte, Ada'daki okulda ve Mecidiye'de olmak üzere farklı yerlerde çeşitli ziyafetlere katılmış olmaktayd1 (Cumburiyet, 13 Şubat 1929, s. 4).

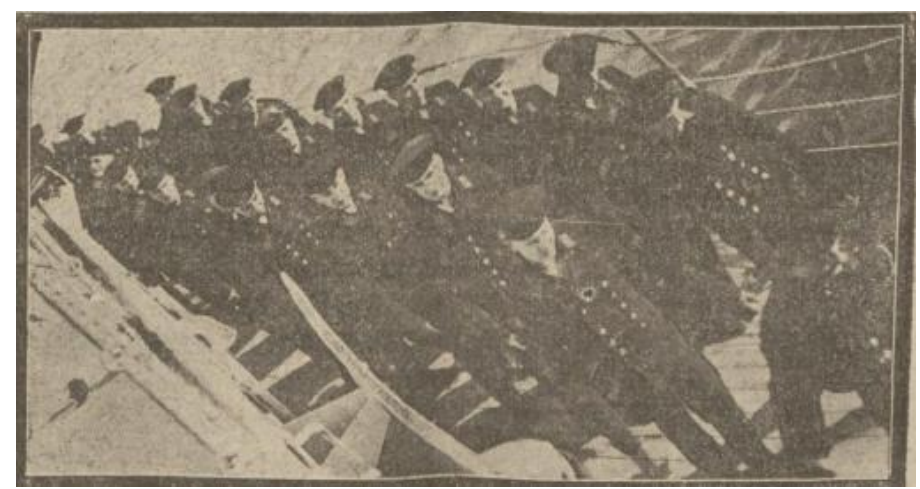

Resim 2. Alman Deniz Harp Okulu Öğrencileri, Heybeliada Deniz Harp Okulunu Ziyaret Ederken (Cumburiyet, 13 Şubat 1929, s. 1).

Havaların bir nebze de olsa düzelmiş olması hem deniz subaylarının Emden’i daha rahat gezmesine ortam sağlamış hem de deniz ve demir yollarının kullanılabilir hale gelmesine vesile olmuştu. Bu durumda, Emden süvarisi ve Alman büyükelçisinin14 Şubat akşam treniyle Ankara'ya gidişi kesinleşti. Süvarinin, Türk hükümet erkânınca Ankara'da karş1lanması ve sefarette bir balo verilmesi uygun görüldü (Son Saat, 14 Şubat 1929, s. 3).

Diğer yandan, yine havaların imkân vermesi sebebiyle, Emden spor kulübüyle yapılacak maç da yeniden gündeme geldi. Stadyumun karla kaplı olması durumu zorlaştırsa da federasyon, buranın temizletilmesi ve bir İstanbul takımılla maç yapılmasının uygun olduğuna karar verdi. (Son Saat, 14 Şubat 1929, s. 4). 
Kruvazör üç gündür İstanbul'daydı ve programı çok yoğundu. Üçüncü günkü resmi kabulün bu kez Alman Okulunda yapılması uygun görüldü. Emden'in süvarisi, öğle saatlerinde okula geldi ve burada şarkılarla karşılandı. Emden'e ait bir kitabı okula hediye etti. Ardından şehri gezdi. Emden Türkiye’ye ilk giriş yaptığında Ankara'ya hem Atatürk'e hem de İsmet Paşa'ya telgrafla bilgi verilmişti. Hatta bir önceki gece Totonya'daki ziyafette Gazi Paşa şerefine kadehler kaldırılmıştı. Şimdi sıra, şerefe kadeh kaldırılan cumhurbaşkanını, Gazi Mustafa Kemal Paşa'yı ziyarete geliyordu. Süvarinin, sefirle birlikte Ankara'ya hareket ettiği haberi basına çoktan yansımıştı (Milliyet, 14 Şubat 1929, s. 1).

14 Şubat günü artık havalar ısınmaya, karlar da temizlenmeye başlamıştı. Emden'in haberlerini takip edenler, sefir ve süvarinin Ankara'daki gezi programını merak ediyorlardı. Fakat, beklenenin aksine o gün gazeteler Emden'le ilgili başka bir haberi manşetten verdi. Emden'in mürettebatı bugün Cumburiyet abidesine merasimle çelenk koyacaklar başlı̆̆1, Ankara'ya gidiş haberini yalanlıyordu. Bu demek oluyordu ki süvari ve büyükelçi Ankara'ya henüz gitmemişti. Bu konu araştırıldığında, Ankara'ya gidişin iki gün sonraya ertelendiği ortaya çıktı. Üstelik aynı akşam, Alman sefirinin İstanbul'daki evinde, Alman denizcileri için bir de balo planlanmıştı. Gündüz planı ise, gazetede yazdığı gibi, süvari ve yanındaki birkaç kişinin saat 12.00'de Taksim'e çelenk koyması şeklindeydi. Bu törene mızıka da eşlik edecekti. Aynı gün, Taksim stadyumunda Emden takımıyla futbol maçı gerçekleşecekti. Fakat kar yeniden bastırınca, maç iptal edildi (Cumburiyet, 14 Şubat 1929, s. 1). Bu konu bir daha da gündeme gelmedi. Aynı akşam, Emden subay ve mürettebatı için Tepebaşında bir temsil verildi. Kendi arzuları üzerine de Karagöz oyunu sergilendi. İzleyenler, Karagöz oyununu çok beğendiklerini, coşkulu alkışlanıla belli etmişlerdi (Milliyet, 16 Şubat 1929, s. 1).

Emden'deki subaylar, 15 Şubat günü mızıkaları önde, İstiklal Caddesini takiben Taksim'e gelecek ve anıta çelenk koyacaklardı (Milliyet, 15 Şubat 1929, s. 3). Büyükelçi ve süvarinin Ankara'ya 17 Şubat Pazar günü gideceği de kesinleşmişti (Son Saat, 15 Şubat 1929, s. 1). 15 Şubat günü gerçekleşen Taksim meydanındaki törende süvari, Cumhuriyet anıtına bizzat kendi çelenk koymak istemişti. Belki Ankara gezisi bu yüzden ertelenmişti. Yüksek rütbeliler saat 12.00 'de tabur halinde şehre çıktılar ve Taksim'e doğru yol aldılar. Diğerleri ise saat 11.00 'de şehre mızıkalarıyla çıktı. Karaköy Şişhane yokuşundan Taksim meydanına geldiler. Abidenin önünde selam verdiler. Süvari bu sırada çelengi abidenin altına koydu. Aynı anda Alman bandosu Türk marşını çalmaya başladı. Merasim, cumhurbaşkanı ve meçhul Türk askerinin selamlanmasıyla sona erdi. O gün hava koşulları çok iyiydi. Kar veya yağmur yağmayacağının haberi meteorolojiden alınmıştı. Diğer yandan Emden'in 16 Şubat günü artık İstanbul'dan ayrılacağı haberi kulaktan kulağa yaylliyordu (İkdam, 15 Şubat 1929, s. 1).

Alman denizcilerinin Taksim abidesine çelenk koyma merasimi ve merasim esnasında İstiklal Marş1 çalarken Emden süvarisinin selam duruşu basında epey ses getirdi. Bandonun abide yanındaki olumlu tavırları, süvarinin Taksime otomobille gelişi ve bizzat kendisi tarafından ön tarafa çelenk konulması, Almanların meşhur marşlarının çalınması ve abide çevresindeki kalabalık epey ilgi çekmişti (Son Saat, 16 Şubat 1929, s. 1). Ertesi gün Ankara’ya gidilecekti. O gün gazeteye yeni bir haber yansıd. Meğerse Emden Çanakkale'den İstanbul'a gelirken, Midilli gemisinin battığ yerde bir dakika durmuş ve denize o noktada bir çelenk bırakmıştı (Cumburiyet, 16 Şubat 1929, s. 3). Bu saygılı davranışları, yine iki ülke arasındaki dostluğu pekiştirecek önemli bir adımdı.

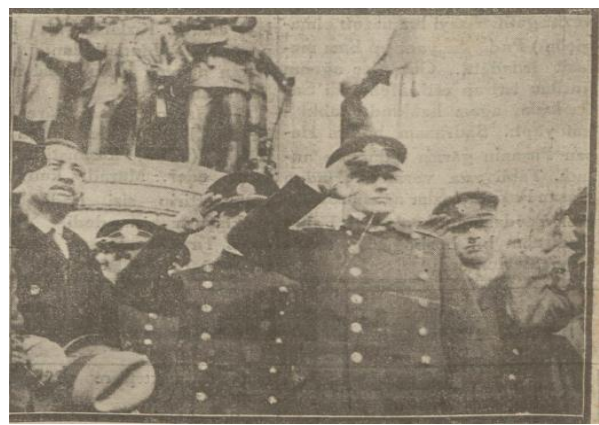

Resim 3. Emden’in Süvarisi Cumhuriyet Abidesi Önünde İstiklal Marşı Çalarken Selam Veriyor (Cumburiyet, 16 Şubat 1929, s. 1). 


\section{Emden Dönüyor}

Emden, 16 Şubat 1929 günü İstanbul gezisini tamamladı. Aynı gün akşam saatlerinde İstanbul'dan çıktı, Akdeniz'e doğru yol aldı. Hareketinden önce, top atarak şehri selamladı, şehirle vedalaştı. Top selamının Selimiye tarafindan yapıldığı ve Emden'in geldiği yoldan, Çanakkale'den dönüş yaptuğı basına yansıdı (Vakit, 17 Şubat 1929, s. 1).

İstanbul'dan ayrilmadan bir önceki gece mürettebat, şereflerine, Nadolny tarafindan verilen baloya katılmıştı. Baloya, Türk hükümetinden önemli kişiler, Türk subayları, Emden subayları ve öğrencileri katılmıştı. Baloda hem İstiklal Marşı hem de Alman Marşı çalındı. Bu baloya katılan Abidin Daver isimli bir gazeteci, tanık olduklarını Türk Marşı başlığıly gazeteye yazmışıı. Bay ve Bayan R. Nadolny'nin özel misafiri olan Daver, balonun sıradan değil özel bir merasimle bittiğini kaleme almıştı. Özellikle Emden mızıkasının çaldığı İstiklal Marşı epey ilgisini çekmişti. Hatta bu konuda bir de eleştiri yapıyordu. Marş çalınmaya başlayınca, çoğu kişi çalınanın İstiklal Marşı olduğunu anlamamıştı. Oysa Alman marşı çaldığında herkes bir anda ayağa kalkmışı. İstiklal Marşının öksüz kaldığını, herkesin bu marşı mutlaka tanıması gerektiğini eleştirel yazısında vurgulamıştı. Gördüğüne göre herkes Alman marşını bir ağızdan söylemişti, oysa Türk marşı coşkusuz kalmıştı (Cumburiyet, 17 Şubat 1929, s. 3). Emden hareket etmeden önce sadece bu balo tertiplenmemişti. Aynı zamanda, Alman deniz subayları, öğleden sonra Tarabya'daki Alman mezarlığını ziyaret etmişler, buraya da çelenk bırakmışlardı. Emden'de bir rahip olduğu, ilk kez orada fark edilmişti. Rahibin, mezarlıkta yaptığı uzun konuşma basına yansıdı (Aķşam, 17 Şubat 1929, s. 1).

Fakat öyle anlaşllyyordu ki sürekli ertelenen Ankara gezisi sessiz sedasız iptal edilmişti. Çünkü Emden 16 Şubat'ta İstanbul'dan Portside'a doğru hareket etmişti. Fakat bazı gazetelere göre 17 Şubat günü öğleden sonra saat 16.00'da hareket edecekti (Son Saat, 17 Şubat 1929, s. 1). Öyle görünüyordu ki, baz1 ajanslar haberleri geç servis ediyordu. Subay ve mürettebatı ise İstanbul'dan çok güzel anılarla ayrıldıklarını belirtmişti. Son geceki baloda ise bin kişinin olduğu, mürettebattan öğrenildi (Milliyet, 17 Şubat 1929, s. 3). Süvari Arnauld ise Vali Muhittin Bey'e, Kolordu ve Deniz Komutanlarına kendilerine gösterilen ilgi için bizzat teşekkür etmişti (İkdam, 17 Şubat 1929, s. 2). Bu şu anlama geliyordu. Türk Alman dostluk ilişkileri, bu ziyaret sayesinde epey pekişmişti. I. Dünya Savaşı'ndaki ittifak sonrası dostluk, bu gezi sayesinde bir kez daha onaylanmıştı. Diğer bir ifadeyle, 1924 yllında imzalanan Türk Alman Dostluk Antlaşması ve 1927 yllında imzalanan karşlıklı ikamet antlaşmalarıyla iki ülke arasında yeniden canlanan diplomatik ilişkiler, bu ziyaretle taçlanmıştı. 16 Mayıs 1929 yllında imzalanacak Türk Alman Hakem ve Uzlaşma ve 28 Mayıs 1929 yıllında imzalanacak karşılıklı Konsolosluk Antlaşmaları (Bütüner, 2015, ss. 265, 266) belki de bu ziyaretle canlanan ilişkiler sayesinde hayata geçmişti. Bütün bu antlaşmalarda katkısı olan büyükelçi Nadolny, 26 Şubat 1929'da Berlin'e, Emden'in İstanbul durağının olağanüstü başarılı bir ziyaret olduğuna dair yazdığı raporunu iletmişti (Koçak, 2013).

Böylece Emden, 11 Şubat 1929-16 Şubat 1929 tarihleri arasında beş gün İstanbul'da kalmış oluyordu. 17 Şubat 1929 sabahı Emden'in, Çanakkale'yi geçtiği haberi geldi. Gemi, Süveyş Kanalı yoluyla Portside'dan Hint Denizine geçecekti (İkdam, 17 Şubat 1929, s. 2). Devrialemde sıra Misır, Çin, Japonya, Avustralya ve Amerika'daydı. Amerika sonrası güzergâh, anavatanı Almanya olacaktı. Emden'in, 13 Aralık 1929'da devrialemi sona erdi. Las Palmas'tan Kanarya Adalan yolundan Almanya'ya, Wilhelmshaven'a yaklaştığında çekilen video görüntüleri ise British Pathé’nin video arşivinde yerini aldı (British Pathé, 1929).

\section{Sonuç}

1929 yllında, dünya büyük bir ekonomik krize sürüklenirken, Almanya’nın I. Dünya Savaşı sonrası inşa ettiği, çağının en modern savaş gemisi olarak adlandırılan Emden kruvazörü, bir dünya turuna çıkmıştı. İsmini, savaşta adından sıkça söz ettiren fakat savaşın sonlarında batırılan Emden'den alan geminin devrialem planı, 30 Ağustos 1928'de yapılmıştı. Tur kapsamındaki duraklarından biri de İstanbul'du ve İstanbul'a geliş tarihi 11 Şubat 1929 olarak belirlenmişti. Türkiye, I. Dünya Savaşından sonra ilk kez bir Alman gemisini ağırlayacaktı. Fakat 1929 yılında, tarihinin en sert kış mevsimlerinden birinin geçirileceği henüz bilinmiyordu.

1929 yll kış mevsimi sadece İstanbul'da değil dünyanın birçok ülkesinde sert geçiyordu. Fakat Emden'in gelişi kapsamında, deniz yolunun açık olması önemliydi. Oysa ki Boğaz kapanmış, şehir içi vapur hatları durmuş, Karadeniz'den ise gemilerin kaybolduğu haberleri gelmişti. Yola çıkan birçok vapur karaya 
oturuyordu. Emden'in Çanakkale yolundan İstanbul'a gelmesi planlanıyordu. Kılavuzu Mecidiye gemisi olacaktı. Fakat Mecidiye Haliç’te demirliydi ve Haliç donmuştu.

Böylesi bir atmosferde dahi Emden, İstanbul'a gelişini ertelememişti. Çünkü devrialeme çıkma sebeplerinden biri ülkeler arası ilişkileri geliştirmekti. Zira dünya Büyük Buhrana sürükleniyordu ve Almanya'nın, bu krizden en çok etkilenen ülkelerden biri olacağını ön görmesi pek de zor değildi. Krizden en az zararla çıkmanın yollarından biri, tanışık olduğu ülkelerle ilişkileri kuvvetlendirmekti. Türkiye, Almanya'nın eski müttefikiydi ve Millî Mücadele sonrası küllerinden yeniden doğmuştu. Ekonomik, sosyal, eğitim ve siyasi alanda, cumhuriyetin çağdaş ve laik politikasına uygun kurum ve kuruluşlarıyla Türkiye, Cumhurbaşkanı Gazi Mustafa Kemal Paşa önderliğinde muasır medeniyetler seviyesine erişiyordu.

Diğer yandan, I. Dünya Savaşı sonrası (1918), Versay ve Sevr Antlaşmaları gereği Osmanlı Almanya ilişskileri durmuştu. Fakat Türkiye, Lozan'ı imzalayarak Sevr’i yok saymıştı ve cumhuriyetin ilanıyla birlikte Türk Alman ilişkileri yeniden canlanmıştı. İlaveten, Türkiye’nin Almanya büyükelçisi Nadolny, bu ilişkilerin eskisinden daha kuvvetli olması için epey çabalamıştı. Sıcak bir ziyaret, bu ilişkileri iyice pekiştirebilirdi. İște bu sebeple, Almanya ve Türkiye, hava ve deniz yolu koşulları uygun olmamasına rağmen bu ziyareti ertelemeyi düşünmediler.

Emden, 11 Şubat 1929 - 16 Şubat 1929 tarihleri arasında İstanbul'a demirledi. Geçirdiği beş gün süresince yapılan planların tamamı ikili ilişkilerin kuvvetlendirilmesi hedefiyle yapıldı. Geliş merasimi, Mecidiye'nin Boğaz'n girişinde Emden'i karşılaması ve karşılığında top atışlarıyla verilen selam bunun ilk somut örnekleriydi. Çanakkale'den geçerken Emden'in motorunu susturup adeta bir anma töreni niteliğinde denize çelenk bırakması, Türkiye'ye karşı gösterilen en büyük sayg1 ifadesiydi. Beş gün boyunca gerek geminin süvarisi gerek mürettebatı gerekse gemideki öğrencilerin kattldığı her etkinliğin özel bir anlamı vard1.

Gemideki harp okulu öğrencilerinin Heybeliada Deniz Harp Okulu'nu ziyaretleri, aday subaylar arasındaki ilişkiyi geliştirmişti. Planlanan, fakat hava muhalefeti sebebiyle iptal edilen futbol maçının, sporcular arasındaki iletişimi geliştireceği düşünülmüştü. Üst düzey subaylara verilen yemek ziyafetleri, ordu ilişkilerini; etkinliklere hem Alman hem Türk basının davet edilmesi gazeteciler arasındaki ilişkiyi güçlendirecekti. Her iki ülkenin millî marşlarının, Cumhuriyet abidesi ve büyükelçi resepsiyonunda çalınması millî duyguları kuvvetlendirecek, eski ittifaka hürmeten dostluk pekişecekti. Darülbedayi ve Tepebaşındaki gösteri ise sanat alanındaki yakınlaşmaya örnekti. Özetle, Emden'in İstanbul durağı, eğitim, spor, askerî, devlet erkânı, basın ve sanat gibi her alanda iki ülkenin yakınlaşmasına vesile oldu.

$\mathrm{Bu}$ ziyarette her iki ülke de güzel anılar biriktirmişti. Ziyafetlerde çekilmiş samimi fotoğraflar bunun en güzel örneğiydi. Beş günün sonunda Emden geri dönüş yolculuğuna çıttı̆̆ında, İstanbul durağı ile birlikte Türkiye ve Almanya arasındaki siyasi ve diplomatik ilişkiler sağlamlaştırldığına emindi. Basına yansıyan haberlerle de bu dostluk uluslararası platforma taşındı. Bu sıcak ilişki, aynı yıl Türkiye ve Almanya arasında imzalanan 16 Mayıs 1929 tarihli Türk Alman Hakem ve Uzlaşma ve 28 Mayıs 1929 tarihli Konsolosluk Antlaşmalarıla taçlandı. Emden, 1929 ylı Türkiye Cumhuriyeti ziyaretiyle amacına ulaşmışıı.

\section{Extended Abstract}

This study is about the Emden cruiser which is the first light cruiser, Germany built after World War I (1914-1918) that anchored in İstanbul during its world tour. Its a known fact that another Emden ship existed which took shelter with its crew within the allied Ottoman Empire territory (1915) during the war. Its deemed important that another German naval vessel with a matching name being in Turkey after fourteen years. Purpose of this study is finding out the cause and effects of this visit in terms of the year 1929.

Year 1929 is important for both İstanbul and world. Winter of 1929 took its place in history as one of the harshest winters of all time. Both bosphorus and bridges closed and ferries stopped working due to blizzard and frost. Same year, the world was trying to deal with a huge economic crysis known as Great Depression. The cruiser's trip to Turkey without altering its original 1928 plan during a hard time like this is considered as an act of favor to improve, repair and solidify the Turkish-German relations.

Emden cruiser which came to Turkey in 1929 is one of the five known Emden ships and no academic researches were found about the mentioned vessel. On the other hand, no documents were found in State 
Archives about this visit. To find information, the Turkish newspapers of that period have been checked, six newspapers which were published in 1929 have been acquired and their February 1929 issues have been browsed completely. Also an internet and publications search was done to find more information which might be done in the later years. In other words, this study is based on published newspapers. Its seen that the newspapers like Akşam, Cumburiyet, İkdam, Milliyet, Son Saat and Vakit have mentioned the cruiser on a daily basis beginning from its arrival date to its departure. The attention of press about the cruiser (even being in the headlines from time to time) just increased our curiosity and resulted in finding the operations of the cruiser during its stop in İstanbul. Our argument is that the visit took place to increase the Turkish - German relarionships which dates back to old times and to demonstrate the strenghtened Turkish - German bonds in international arena.

Base finding in this study is that the winter of 1929 was very harsh in İstanbul. The dead of winter which started in January turned into a blizzard in February and resulting in the closure of sea traffic. In this setting, there were many news about marine accidents, Haliç being frozen and ferries being stuck in the sea. There was a heavy snowfall and the city municipality was trying to break the ice in Haliç on 11th of February when Emden was arriving to Istanbul. On the other side, world was being dragged into a massive economic crisis. Germany who was already suffering from Versailles Treaty's (1920) articles which was signed after the World War I, also got deeply affected from the mentioned crisis. As Germany learned its lesson from previous experiences, decided to strenghten the bonds with other countries to reduce the damage.

In 11 February 1929, Emden cruiser arrived to the port of İstanbul as planned. Cruiser was hailed with cannon fires. During the five day stay, shipmaster and soldiers attended to ceremony, banquet and several visits. They also attended to dinners given in the Embassy. Beside the official receptions on land, also some banquets served on Emden deck. The visitation of Heybeliada Naval Academy by Emden's naval students was a trumpeted event. On the second day of cruisers arrival, a special tour was prepared on ship for Turkish Naval Forces Commander. All the Turkish, minority and foreign press was invited to this tour. There was a photo exhibit on the ship but the football tournament and Ankara tour was cancelled. The placing a wreath on Taksim Monument by Emden officers was another trumpeted event. After the Ankara tour being cancelled, the officers took their time to visit Taksim after İstiklal Street. Shipmaster placed his own wreath to Republic Monument. Emden has completed its İstanbul visit on 16 February 1929. Cruiser left the city on the night of the same day and saluted the city by cannon fires.

One of the reasons behind Emden's world tour regardless of those times hard geographic and economic conditions was strengthening the international relations. Old ally Turkey who stood as a strong nation state after the war should have been one of those countries.

With this study, Emden's Turkey trip and its activities during its stay in İstanbul were examined first time ever in academic field and a gap in literature has been filled. It has been concluded that the visit had strenghtened the paused Turkish-German relations and served its purpose well.

\author{
Kaynakça \\ Gazeteler \\ Akşam, 17 Şubat 1929. \\ Cumburiyet, 1 Şubat 1929-17 Şubat 1929. \\ İkdam, 2 Şubat 1929-17 Şubat 1929. \\ Milliyet, 2 Şubat 1929- 17 Şubat 1929. \\ Son Saat, 4 Şubat 1929-17 Şubat 1929. \\ Vakit, 17 Şubat 1929.
}

\title{
Diğer Kaynaklar
}

Aykun, İ. ve Yeşilyurt Y. (2015). I. Dünya Savaşında Efsane Kruvazör Emden Mürettebatının Yemen'e Varışları ve Osmanlı Devleti'ne Sığınmaları, Mediterraneas Journal of Humanities, 5 (2), 93-122. Doi: 10.13114/MJH.2015214562.

Bütüner, Z. (2015). Rudolf Nadolny'nin Türkiye Büyükelçiliği, International Journal of Social Sciences and Education Research, 2 (1), 262-273. 
British Pathé (1929). This Emden-Got Home. https://www.britishpathe.com/video/this-emden-gothome/query/emden, [Erişim tarihi: 07.07.2020].

Eichengreen, B. (2015). Hall of Mirrors: The Great Depression, The Great Recession. New York: Oxford University Press.

Gürün, K. (1986). Savaşan Dünya ve Türkize. Ankara: Bilgi Yayınevi.

Üzen, İ. (2010). Alman Kruvazörü Emden Mürettebatının Osmanlı Topraklarındaki Serüveni (1915), Furat Üniversitesi Sosyal Bilimler Dergisi, 20 (2), 361-381.

Kahraman, C. (2007). 1929 Kışı Bir Şehir Efsanesi, İstanbul: Türkiye İş Bankası Kültür Yayınlanı.

Koçak, C. (2013). Almanların İlk Göz Ağrns1 Emden Türkiye'ye Neden Geldi? https://www.star.com.tr/yazar/almanlarin-ilk-goz-agrisi-emden-turkiyeye-neden-geldi-yazi-791190/, [Erişim tarihi: 07.07.2020].

Temin, P. (2010). The Great Recession and The Great Depression, National Bureau of Economic Research, $1-17$. 